\title{
Allophlebia, A New Genus to Accomodate Phlebia Ludoviciana (Agaricomycetes, Polyporales)
}

Carla Rejane de Sousa Lira

Universidade Federal de Pernambuco

Renata dos Santos Santos Chikowski ( $\square$ renatachikowski@hotmail.com )

Universidade Federal de Pernambuco https://orcid.org/0000-0003-2162-7024

Vítor Xavier de Lima

Universidade Federal de Pernambuco

Karl-Henrik Larsson

Natural History Museum: Naturhistorisk Museum

Tatiana Baptista Gibertoni

Universidade Federal de Pernambuco

\section{Research Article}

Keywords: Atlantic Rainforest, Caatinga, Brazil, Basidiomycota, corticioid fungi, new taxon

Posted Date: June 17th, 2021

DOI: https://doi.org/10.21203/rs.3.rs-613486/v1

License: (c) (i) This work is licensed under a Creative Commons Attribution 4.0 International License.

Read Full License 


\section{Abstract}

Allophlebia is proposed as a new genus in Meruliaceae based on morphological characters and molecular data. The genus is typified by Peniophora ludoviciana and the new combination A. Iudoviciana is proposed. The genus is so far monotypic. The type species is characterized by a resupinate basidioma, a monomitic hyphal system with clamp connections, two types of cystidia (leptocystidia and metuloids), clavate basidia, and hyaline, thin-walled and ellipsoid basidiospores. A phylogeny for Allophlebia and related taxa was inferred from ITS and nLSU rDNA sequences and new information about the geographic distribution of $A$. ludoviciana is provided.

\section{Introduction}

Phlebia Fr. (Polyporales, Meruliaceae) was described by Fries in 1821 and intended for species with a hymenium composed of irregular veins and ridges. Fries (1828) pointed to $P$. radiata as the most typical member of his new genus and this species is now generally accepted as the type (Donk 1957). Species in Phlebia sensu lato usually have resupinate basidiomata that are ceraceous to subgelatinous in fresh specimens, and with a membraneous or coriaceous consistency when dry. The hymenial surface varies from smooth, tuberculate, phlebioid, odontoid, merulioid to poroid. The hyphal system is monomitic, rarely dimitic, with hyphae clamped and embedded in a more or less evident gelatinous matrix. Cystidia can be present or absent, basidia are clavate, narrow, with a basal clamp and disposed in a dense palisade, and basidiospores are allantoid to ellipsoid, smooth, thin-walled, IKI- and CB- (Eriksson et al. 1981; Bernicchia \& Gorjón 2010). All species analyzed are saprobes on decaying wood (Nakasone 1990).

The original concept for Phlebia was successively considerably broadened (Donk 1931, 1957, Nakasone 1991, 1996, 1997, 2002, Nakasone \& Burdsall 1984). However, this wider concept for Phlebia is clearly polyphyletic (Larsson et al. 2004, Binder et al. 2013, Floudas \& Hibbett 2015, Justo et al. 2017). Several genera have been introduced or resurrected to accommodate species from Phlebia, e.g. Cabalodontia, Crustodontia, Hermanssonia, Jacksonomyces, Lilaceophlebia, Mycoacia, Mycoaciella, Phlebiopsis, Scopuloides, and Stereophlebia. Other Phlebia species have been moved to other genera, most notably to Crustoderma and Resinicium. After such removal and transfer of species and after adjustments for synonyms the genus still holds around 100 species, many of which are based on names for which there are no modern interpretation (www.mycobank.org). According to molecular data, $P$. radiata, the type species, and quite many other Phlebia species belong in Meruliaceae in Polyporales (Justo et al 2017), while a few are recovered in Hymenochaetales (Larsson 2007).

During studies of corticioid fungi from Northeast Brazil, specimens of Phlebia ludoviciana were collected. Molecular analyses showed that this species could not be placed in any of the phlebioid genera already described. Thus, the aims of this paper are to describe a new genus for $P$. ludoviciana and to discuss the geographical distribution of that species.

\section{Material And Methods}


Field trips were undertaken in Northeast Brazil in the Atlantic Rainforest [Reserva Biológica de Pedra

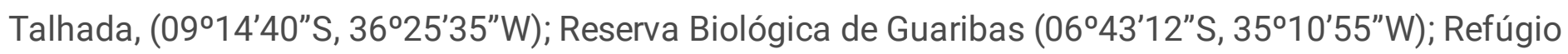
Ecológico Charles Darwin (07049'42"S, 3452'29”W), Reserva Particular do Patrimônio Natural (RPPN) Frei Caneca $\left(08^{\circ} 42^{\prime} 41^{\prime \prime} \mathrm{S}, 35^{\circ} 50^{\prime} 30^{\prime \prime} \mathrm{W}\right)$, Reserva Biológica de Saltinho $\left.\left(8^{\circ} 44^{\prime} 16.9^{\prime \prime} \mathrm{S}, 35^{\circ} 10^{\prime} 22,6^{\prime \prime} \mathrm{W}\right)\right]$ and in montane forest (Brejos Nordestinos) in Caatinga; Reserva Ecológica Estadual Mata do Pau-Ferro $\left(06^{\circ} 58^{\prime} 12^{\prime \prime} S, 35^{\circ} 42^{\prime} 15^{\prime \prime} \mathrm{W}\right)$.

Specimens were identified based on macro- (measures, texture, consistency, shape and color of the basidiomata) and micro-morphology through slide preparations with $3 \%$ potassium hydroxide solution $(\mathrm{KOH})$, stained with $1 \%$ aqueous phloxine. Melzer's reagent and Cotton Blue were used to analyze, respectively, dextrinoid and amyloid (IKI+/IKI-), and cyanophilous (CB+/CB-) reactions of the microstructures. Presence/absence of sterile structures and basidiospores were noted and measurements of at least 20 of them taken, when possible (Hjortstam et al. 1987; Watling 1969). The material was deposited in the Herbarium Pe. Camille Torrend (URM), Departmento de Micologia (UFPE), and in the Herbarium of the University of Oslo (0).

DNA extraction, PCR amplification and sequencing

Basidiomata fragments (30-50 mg) were removed, placed in tubes of $1.5 \mathrm{ml}$ and stored at $-20^{\circ} \mathrm{C}$ until DNA extraction. The method of DNA extraction followed Góes-Neto et al. (2005) and the reaction mix and parameters for PCR reactions of the ITS and LSU regions were according to Smith \& Sivasithamparam (2000), using the primer pairs ITS4-ITS5 and LROR-LR5, respectively (White et al. 1990, Moncalvo et al. 2000, Lima-Junior et al. 2014). The purification of PCR products was done with ExoSAP-IT ${ }^{\mathrm{TM}}$ PCR Product Cleanup Reagent (Thermo Fisher Scientific, USA), following the manufacturer's recommendations. The samples were sequenced at the Plataforma Tecnológica de Genômica e Expressão Gênica do Centro de Biociências (CB), UFPE, Brazil, in an ABI-310 Capillary Sequencer (PerkinElmer, Wellesley Massachusetts, USA). The cycle sequencing was carried out with the same primers of PCR reactions (Moncalvo et al. 2000). All obtained sequences were deposited in GenBank (National Center for Biotechnology Information, Bethesda, Maryland, USA). Attempts at sequencing RBP1, RBP2 and TEF resulted in only one low quality TEF sequence that could not be submitted to GenBank (available on request).

\section{Phylogenetic analyses}

The 2.0 Staden Package software was used for analyses and edition of electropherograms (Bonfield et al. 1995). These sequences were subjected to BLASTn search in NCBI to recover similar sequences from GenBank and used in the dataset to establish phylogenetic relationships (Table 1). Each gene region was aligned with the MAFFT v.7 online server using default settings (http://mafft.cbrc.jp/alignment/server/), then improved manually using MEGA 7.0 and combined to form the concatenated dataset (Kumar et al. 2016). 
The ITS and LSU regions were first analyzed independently (data not shown). Since no important topological differences were detected, the regions were combined into a single matrix for the final analyses. The models of evolution were obtained from MEGA 7.0 (Kumar et al. 2016) and confirmed in TOPALi v2.5 (Milne et al. 2004) for each dataset. Phylogenetic analyses and tree construction were performed using Maximum Likelihood (ML) and confirmed in Bayesian Algorithm (BA). ML analysis was performed using MEGA 7.0 (Kumar et al. 2016) with 5000 bootstrap replications and based on GTR + G + I model. BA analyses were run in TOPALi v2.5 (Milne et al. 2004) with $5 \times 10^{6}$ generations, also based on $\mathrm{GTR}+\mathrm{G}$ model. Statistical support for branches was considered informative with Bayesian posterior probabilities (BPP) $\geq 0.80$ and bootstrap (BS) values $\geq 70 \%$. The trees were visualized with FigTree (Rambaut 2014) and the layouts were done in the software Microsoft PowerPoint.

\section{Results}

Five specimens were sequenced (URM 93082, URM 93251, URM 93329, 0-F-110340, 0-F-110341), generating five ITS and four LSU sequences (Table 1). These were combined with ITS and LSU sequences selected though BLAST searches against GenBank.

No strongly supported topological conflict was detected among the datasets analyzed (ITS, LSU and ITS + LSU) in the present study, thus only the combined analysis is presented here, performed mainly with ITS sequences since only that region is available for some key specimens. The combined dataset included 174 sequences (116 ITS and 58 LSU), with Climacocystis borealis (Fr.) Kotl. \& Pouzar and Junghuhnia nitida (Pers.) Ryvarden as outgroup following Shan et al. (2018) (Table 1), and comprised 2138 characters including gaps.

The results of the phylogenetic analyses generated from $M L$ and BA showed similar tree topologies and small or insignificant differences in statistical support values. Thus, the $M L$ tree with bootstrap support values (BS) and posterior probabilities (PP) from Bayesian Inference of phylogeny (BI) was used to show the results of this study (Fig. 1).

The newly generated sequences are placed in a strongly supported clade (BS 99\%, PP 0.99) with several samples of A. ludoviciana as well as other samples identified differently, previously deposited in GenBank. The A. Iudoviciana clade is sister to a clade formed by Phlebia ochraceofulva and one unidentified sample and is genetically separated from the clade representing Phlebia s.s, typified by $P$. radiata, and from other described genera (Fig. 1).

\section{Taxonomy}

Allophlebia C.R.S. de Lira, Gibertoni \& K.H. Larss., gen. nov.

Mycobank: MB 838838

Etymology-Allophlebia (Gk) = "allo-" other, different; "-phlebia" referring to genus Phlebia. 


\section{Description}

Basidiomata resupinate, effused, adnate, ceraceous; hyphal system monomitic, all septa with clamps; thin-walled smooth leptocystidia and thick-walled encrusted cystidia present; basidia clavate, with four sterigmata; basidiospores ellipsoid, thin-walled, smooth, inamyloid, indextrinoid and acyanophilous.

Type species: Peniophora ludoviciana Burt

Allophlebia ludoviciana (Burt) C.R.S. de Lira \& K.H. Larss., comb. nov., Fig. 2a-f

Mycobank: MB 838839

Basionym: Peniophora Iudoviciana Burt, Annals of the Missouri Botanical Garden 12 (3): 244 (1926)

Description: Nakasone et al. (1982).

Remarks: Allophlebia is so far monotypic. Allophlebia ludoviciana is characterized by a resupinate, ceraceous and golden yellow to deep orange basidioma (Fig. 2a-b), a smooth to minutely warted hymenophore without reaction in $3 \% \mathrm{KOH}$, and a monomitic hyphal system. Two types of cystidia can be observed: 1) Leptocystidia, narrowly obclavate to ventricose, hyaline and projecting above the hymenium, (35) 45-70 × 5.5-7 $\mu \mathrm{m}$ (Fig. 2e), and 2) Cylindrical metuloids, heavily encrusted with hyaline crystals, with obtuse to slightly conical apex, immersed in the hymenium, 35-70 $\times 6-9 \mu \mathrm{m}$ (Fig. 2f). The basidia are narrowly clavate and the basidiospores are ellipsoid, (4.5)5.5-6.5 $\times 2-2.5 \mu \mathrm{m}$, smooth, thin-walled, hyaline (Fig. 2f) and IKI- and CB-. Allophlebia ludoviciana and Phlebia subochracea are both bright yellow-orange when fresh and tan to light brown when dry. However, $P$. subochracea has longer and narrower basidiospores $(5-7 \times 1.5-2 \mu \mathrm{m})$ and lacks the metuloids found in A. ludoviciana (Nakasone et al. 1982).

Distribution: Allophlebia ludoviciana and specimens of this species identified differently were reported as saprobes, endophytes or as airborne basidiospores from Jamaica, Saint Lucia and United States of America (Nakasone et al. 1982, Ritttenour et al 2014), Cuba and Bermudas (Hjorstam \& Ryvarden 2001), Mexico (Tapia \& Chacón 2015), Ecuador, French Guyana, China and possibly Colombia (Fig. 1, Table 1). Here the presence in Brazil is confirmed (Fig. 1, Table 1). The Brazilian specimens studied by us were collected on decaying wood in Atlantic Rainforest (Southeast and Northeast Brazil) and montane forests in Caatinga (Brejos Nordestinos). In addition, there is a report of $A$. Iudoviciana from the Southeastern Atlantic Rainforest identified as Grammothelopsis puiggarii (Table 1).

Material examined: Brazil: Alagoas, Quebrangulo, Reserva Biológica Pedra Talhada, leg. R.L.M. Alvarenga \& A. Meiras-Ottoni, A., 6 June 2017, RC38 (URM93082), Ibid, leg. V. Xavier de Lima, 19 Sep. 2018, VXL550 (URM93250), Ibid, 20 Sep. 2018 VXL591 (URM93251); Paraiba, Areia, Reserva Ecológica Estadual Mata do Pau-Ferro, 29 April 2013, C.R.S. Lira 583 (URM 93329), Ibid. K.H. Larsson 16092 (O-F-110341), Ibid, Mamanguape, Reserva Biológica Guaribas, 30 May 2015, R.S. Chikowski 1300 (URM92973); Pernambuco, Cabo de Santo Agostinho, 7 June 2018, VXL155 (URM93249); Ibid, Igarassu, Refúgio 
Ecológico Charles Darwin, 12 May 2017, R.S. Chikowski 1536 (URM93061), Ibid, Jaqueira, RPPN Natural Frei Caneca, 30 Sep. 2012 R.S. Chikowski 381 (URM92972), Ibid, 9 March 2013, R.S. Chikowski 548 (URM85875); São Paulo: Santos, Cananeia, Ilha do Cardoso, 2- 5 Feb. 1987, L. Ryvarden 24695 (O-F110338); São Paulo: São Paulo, Parque Estadual Fontes do Ipiranga, 16-24 Jan. 1987, K. Hjortstam 16335 (SP213701); Ibid L. Ryvarden 24141 (O-F-110339). Colombia: Magdalena, Parque Nacional Tayrona, Estacion de Gairaca, 12 June 1978, L. Ryvarden 15780 (O-F-918462). Ecuador: Orellana, Yasuni Nat. Park, Yasuni Research St., 9-12 Mar. 2002, L. Ryvarden 44743 (O-F-110340). USA: lowa, lowa City, 8 July 1934, D.P. Rogers 104 (O-F-504275); Louisiana, Plaquemines Parish, F. Edward Hebert Center, 26 July 1972, W.B. \& V.G. Cooke 45633 (O-F-908538).

\section{Discussion}

When combining Peniophora ludoviciana to Phlebia, Nakasone et al. (1982) grouped this species with $P$. brevispora, $P$. subochracea and $P$. subserialis in the section Leptocystidiophlebia based on morphology and culture characteristics. Our results, however, show that although $P$. ludoviciana is close to $P$. subochracea, $P$. brevispora and $P$. subserialis are distantly related from each other and from $P$. Iudoviciana and $P$. subochracea (Fig. 1), similar to the findings of other studies. Floudas \& Hibbett (2015) included $P$. brevispora (HHB7030) and several samples identified as $P$. subserialis and $P$. subochracea (EU 118656) in their analyses. Phlebia brevispora is placed in the Phlebia s.s. clade, while the samples identified as $P$. subserialis are placed in three different clades, one corresponding to A. Iudoviciana (HQ607954, HM997135, HQ377286, KP135343, HQ248219, FD427, HHB9768) and sister to P. subochracea (EU118656), one close to P. nothofagi and P. fuscoatra (AF141631), currently belonging to Mycoacia, and the last one belonging to the Phanerochaete clade (AY219365, JN017928, HHB-5796). Justo et al. (2017) did not include $P$. subserialis in their study, but $P$. ludoviciana (FD-427) is placed in a clade with $P$. subochracea I (HHB8715), both representing A. Iudoviciana and sister to P. subochracea II (HHB8494), an undescribed species of Allophlebia, all of them distantly related from P. brevispora (FBCC1463 or HHB7030, not detailed in their Fig. 5) and from $P$. radiata. Shen et al. (2018) did not include $P$. brevispora in their analyses, but $P$. Iudoviciana (FD-427) is again sister to $P$. subochracea (HHB8715), both corresponding to $A$. Iudoviciana and distantly related from $P$. radiata and the sample identified as $P$. subserialis (AF141631).

In our study, the Allophlebia clade is genetically separated from the Phlebia s.s. clade $(B S=87 / P P=0.96$, with $P$. radiata) as well as from other genera in Meruliaceae and from remaining sequenced species of Phlebia recovered outside of Meruliaceae. It is strongly supported as a monophyletic group (99) (Fig. 1), in accordance with the recommendations by Vellinga et al. (2015). The new genus may also include Fungal sp. (TP2) from Thailand (Klomklieng et al. 2014) and P. ochraceofulva FBCC295 with unknown origin (Kuuskeri et al. 2015), but they represent isolates without vouchers, which prevents morphological studies.

The sequences of $A$. ludoviciana generated in our study clustered with 17 sequences from the USA and French Guiana and 14 other sequences that also represent $A$. Iudoviciana, but were identified differently: 
P. aff argentina from French Guiana, $P$. subserialis from Brazil, China, Ecuador, the USA and possibly from Colombia, Phlebia cf. subserialis from the USA and Grammothelopsis puiggarii from Brazil and possibly China, as well as unidentified fungal samples from the USA and Mexico (Table 1), forming a distinct, strongly supported clade (BS = 99/PP = 0.99) (Fig. 1). Phlebia argentina (Speg.) Rajchenb. \& J.E. Wright, originally collected on Salix humboldtiana in Argentina, is characterized by membraneous basidiomata and one kind of cystidia, strongly encrusted metuloids projecting beyond the hymenium (Rajchenberg \& Wright 1987). The type of $P$. subserialis is from France and sequences from there and other European countries, as well as one sequence of material from India (Table 1), are distantly placed in the phylogenetic tree (Fig. 1). In addition, $P$. subserialis has narrower leptocystidia (3-4 $\mu \mathrm{m})$, lacks encrusted cystidia, and has longer, sub-allantoid basidiospores [6-7(-8) x 2-2.5 $\mu \mathrm{m}]$ (Bernicchia \& Gorjón, 2010). Thus, specimens of $P$. subserialis reported in the Americas should be reevaluated (Nakasone et al. 1982). Grammothelopsis puiggarii is a species characterized by large, angular pores (1-2 per mm), large, dextrinoid, thick-walled basidiospores and dextrinoid skeletal hyphae (Rajchenberg \& Wright 1987). This species is currently placed in Polyporaceae and the sequences clustering with A. Iudoviciana are clearly misidentified.

This study improved the circumscription and the knowledge about the distribution of a species previously placed in Phlebia. The results also indicate that Phlebia s.s. is still in need of rearrangement and for these taxonomical approaches including morphology, DNA analyses and geographical data are strongly encouraged.

\section{Declarations}

Funding - This research was funded by CNPq (563342/2010-2, 457476/2012-5, 307601/2015-3, 421241/2017-9), CAPES (Capes-SIU 008/13, CRLS and RSC scholarships) and FACEPE (ATP-00212.03/18, APQ-0788-2.03/12, CRLS, RSC and VXL scholarships)

Conflicts of interest/Competing interests (include appropriate disclosures) - Not applicable

Ethics approval - Not applicable

Consent to participate - Not applicable

Consent for publication - Not applicable

Availability of data and material - All material is deposited in Herbarium URM and 0 . The sequences is deposited in GenBank. Data will be available online after the acceptance of the manuscript in http://www.splink.org.br/ and https://www.ncbi.nlm.nih.gov/genbank/.

Code availability - Not applicable

Authors' contributions - All authors contributed to the study conception and design. Material preparation, data collection and analysis were performed by all authors. The first draft of the manuscript was written 
by Carla Rejane de Sousa Lira and all authors commented on previous versions of the manuscript. All authors read and approved the final manuscript. Karl-Henrik Larsson and Tatiana B. Gibertoni provided funds and supervised this research.

\section{References}

1. Baltazar J, Silveira R, Rajchenberg M (2016) Type studies of J. Rick's corticioid homobasidiomycetes (Agaricomycetes, Basidiomycota) housed in the Herbarium Anchieta (PACA). Phytotaxa 255(2):101132

2. http://dx.doi.org/10.11646/phytotaxa.255.2.1

3. Bernicchia A, Gorjón SP (2010) Corticiaceae s.I. Fungi Europaei vol, 12. Edizioni Candusso, Alassio

4. Binder M, Justo A, Riley R, Salamov A, Lopez-Giraldez F, Sjökvist E, Copeland A, Foster B, Sun H, Larsson E, Larsson K-H, Townsend J, Grigoriev IV, Hibbett DS (2013) Phylogenetic and phylogenomic overview of the Polyporales. Mycologia 105(6):1350-1373. http://dx.doi.org/10.3852/13-003

5. Bonfield JK, Smith K, Staden R (1995) A new DNA sequence assembly program. Nucleic Acids Res 24:4992-4999. http://dx.doi.org/10.1093/nar/23.24.4992

6. Eriksson J, Hjortstam K, Ryvarden L (1981) The Corticiaceae of North Europe. Volume 6. Phlebia Sarcodontia. Oslo, Norway, Fungiflora, $225 \mathrm{p}$

7. Floudas D, Hibbett DS (2015) Revisiting the taxonomy of Phanerochaete (Polyporales, Basidiomycota) using a four gene dataset and extensive ITS sampling. Fungal Biology 119:679719. http://dx.doi.org/10.1016/j.funbio.2015.04.003

8. Goés-Neto A, Loguercio-Leite C, Guerrero RT (2005) DNA extraction from frozen field collected and dehydrated herbarium fungal basidiomata: performance of SDS and CTAB based methods. Biotemas 18(2):19-32

9. Hjortstam K, Larsson K-H, Ryvarden L (1987) The Corticiaceae of North Europe (Introduction and Keys). Fungiflora, Oslo, Norway, $59 \mathrm{pp}$

10. Justo A, Miettinen O, Floudas D, Ortiz-Santana B, Sjökvist E, Lindner D, Nakasone K, Niemelä T, Larsson K-H, Ryvarden L, Hibbett DS (2017) A revised family-level classification of the Polyporales (Basidiomycota). Fungal Biology 121:798-824. http://dx.doi.org/10.1016/j.funbio.2017.05.010

11. Klomklieng P, Thanananta T, Sakkayawong N, Somrithipol S (2014) Identification of Reactive Red 141 Degradable Fungi by ITS-PCR Method and Decolorization Ability. Thammasat Journal of Science Technology 22:683-694

12. Kuuskeri J, Mäkelä MR, Isotalo J, Oksanen I, Lundell T (2015) Lignocellulose-converting enzyme activity profiles correlate with molecular systematics and phylogeny grouping in the incoherent genus Phlebia (Polyporales, Basidiomycota). BMC Microbiol 15:217-235. http://dx.doi.org/10.1186/s12866-015-0538-x

13. Kumar S, Stecher G, Tamura K (2016) MEGA7: Molecular Evolutionary Genetics Analysis Version 7.0 for Bigger Datasets. Mol Biol Evol 35: 1547-1549. http://dx.doi.org/10.1093/molbev/msw054 
14. Larsson K-H, Larsson E, Kõljalg U (2004) High phylogenetic diversity among corticioid homobasidiomycetes. Mycol Res 108:983-1002. https://doi.org/10.1017/S0953756204000851

15. Milne I, Wright F, Rowe G, Marshall DF, Husmeier D, McGuire G (2004) TOPALi: software for automatic identification of recombinant sequences within DNA multiple alignments. Bioinformatics Applications Note 20(11):1806-1807. https://doi.org/10.1093/bioinformatics/bth155

16. Moncalvo JM, Lutzoni FM, Rehner SA, Johnson J, Vilgalys R (2000) Phylogenetic relationships of agaric fungi based on nuclear large subunit ribosomal DNA sequences. Syst Biol 49:278-305

17. Nakasone KK, Burdsall HH, Noll LA (1982) Species of Phlebia section Leptocystidiophlebia (Aphyllophorales, Corticiaceae) in North America. Mycotaxon 14(1):3-12

18. Nakasone KK (1990) Cultural studies and identification of wood-inhabiting Corticiaceae and selected Hymenomycetes from North America. Mycologia Memoir 15:1-412

19. Nakasone KK (1991) Molecular systematics of Phlebia (Aphyllophorales, Basidiomycotina, Corticiaceae). Dissertation PhD, Univ. Wisconsin, Madison, Wisconsin

20. Nakasone KK (1996) Morphological and molecular studies on Auriculariopsis albomellea and Phlebia albida and a reassessment of $A$. ampla. Mycologia 88:762-775

21. Nakasone KK (1997) Studies in Phlebia. Six species with teeth. Sydowia 49:49-79

22. Parmasto E (1997) Cortbase - a nomenclatural database of corticioid fungi (Hymenomycetes). Mycotaxon 61:467-471

23. Parmasto $E$, Hallenberg N (2000) A taxonomic study of phlebioid fungi (Basidiomycota). Nordic Journal of Botany 20(1):105-118. https://doi.org/10.1111/j.1756-1051.2000.tb00740.x

24. Posada D (2008) jModelTest: phylogenetic model averaging. Mol Biol Evol 25:1253-1256

25. https://doi.org/10.1093/molbev/msn083

26. Rajchenberg M, Wright JE (1987) Type studies of Corticiaceae and Polyporaceae (Aphyllophoralles) described by C. Spegazzini Mycologia 79(2):246-264

27. Rambaut A (2014) FigTree v. 1.4.2. Avaliable at < http://tree.bio.ed.ac.uk/software/figtree/>

28. Rittenour WR, Ciacci CE, Barnes CS, Kashon ML, Lemons AR, Beezhold DH, Green BJ (2014) Internal transcribed spacer rRNA gene sequencing analysis of fungal diversity in Kansas City indoor environments. Environmental Science: Processes Impacts 16(1):33-43.

https://doi.org/10.1039/C3EM00441D

29. Shen S, Ma X, Xu T-M, Zhao C-L (2018) Phlebia ailaoshanensis sp. nov. (Polyporales, Basidiomycota) evidenced by morphological characters and phylogenetic analyses. Phytotaxa 373(3):184-196. https://doi.org/10.11646/phytotaxa.373.3.2

30. Smith BJ, Sivasithamparam K (2000) Isozymes of Ganoderma species from Australia. Mycol Res 104(8):952-961. https://doi.org/10.1017/S0953756200002446

31. Tapia F, Chacón S (2015) Registros de hongos corticióides de la familia Meruliaceae (Polyporales, Agaricomycetes) de Veracruz, México. Revista Mexicana de Micologia 41:5-13 
32. Vellinga EC, Kuyper TW, Ammirati J, Desjardin DE, Halling RE, Justo A, Læssøe T, Lebel T, Lodge DJ, Matheny PB, Methven AS, Moreau PA, Mueller GM, Noordeloos ME, Nuytinck J, Ovrebo CL, Verbeken A (2015) Six simple guidelines for introducing new genera of fungi. IMA Fungus 6:65-68. https://doi.org/10.1007/BF03449356

33. Watling R (1969) Colour Identification Chart. Her Majesty's Stationary Office, Edinburgh

34. White TJ, Bruns T, Lee S, Taylor JW (1990) Amplification and direct sequencing of ribosomal RNA genes for phylogenetics. In: Innis MA, Gelfand DH, Sninsky JJ, White TJ (eds) PCR Protocols, a Guide to Methods and Applications. Academic Press, New York, pp 315-322

35. Zhao C-L, Liu S-L, Ren G-J, Ji X-H, He S (2017) Three species of wood-decaying fungi in Polyporales new to China. Mycotaxon 132:29-42. http://dx.doi.org/10.5248/132.29

\section{Tables}

Table 1 Sequences of Meruliaceae used in this study with vouchers, locality and GenBank accession numbers for the ITS and LSU regions. The sequences in bold were generated in this study. 


\section{Species}

Voucher/Locality Locality

ITS

LSU

Allophlebia ludoviciana

A. ludoviciana

A. ludoviciana

A. ludoviciana

A. ludoviciana

Climacocystis borealis (Fr.) Kotl. \&

Pouzar

Climacodon septentrionalis (Fr.) P.

Karst.

Crustodontia chrysocreas (Berk. \&

M.A. Curtis) Hjortstam \& Ryvarden

C. chrysocreas

C. chrysocreas

C. chrysocreas

Fungal sp.

Fungal sp.

Geesterania carneola (Bres.)

Westphalen \& Rajchenberg

Geesterania davidii Westphalen \&

Rajchenberg

Grammothelopsis puiggarii (Speg.)

Rajchenb. \& J.E. Wright

G. puiggarii

Hydnophlebia canariensis Telleria, M.

Dueñas \& M.P. Martín (Type)

H. canariensis

H. gorgonea Telleria, M. Dueñas \& M.P. Martín

H. gorgonea

URM $93082 \quad$ Brazil MN044657 -

$\begin{array}{llll}\text { URM } 93251 & \text { Brazil } & \text { MN044659 } & \text { MN044661 }\end{array}$

$\begin{array}{llll}\text { URM } 93329 & \text { Brazil } & \text { MN044658 } & \text { MN044660 }\end{array}$

O-F-110340 Ecuador MT974604 MT982121

$\begin{array}{llll}\text { O-F-110341 Brazil } & \text { MT974603 } & \text { MT982120 }\end{array}$

KHL13318

Estonia JQ031126 -

RLG-6890

USA

KP135344

HHB-3946

USA

KP135357

FCUG2827

USA

KY948764

KUC20121123-

24

South

KJ668482

KJ668335

Korea

CLZhao 851

China

MG231783 -

MX417

Mexico

JQ919918

TP2

Thailand

MCW 388/12

Brazil

KF860888

KY174999

KY174999

MCW 370/12

Brazil

KY174997

KY174997

RP 134

Brazil

KP859299

KP859308

WZ-143

China (?)

MN856289

MA-Fungi 86622 Spain

KF528103

KF528103

MA-Fungi $86623 \quad$ Spain

KF483013

KF528104

MA Fungi 86659

Cape

Verde

KF483049

KF528140

MA Fungi 86658

Cape

Verde 
ITS

LSU

H. meloi Telleria, M. Dueñas \& M.P. Martín

H. omnivora (Shear) Hjortstam \& Ryvarden

\begin{tabular}{|lllll}
\hline H. omnivora & KKN-112 & USA & KP135334 & KP135216 \\
\hline H. subchrysorhiza Hai X. Ma \& S.H. He & Cui 16185 & China & MK860722 & MK860739 \\
\hline $\begin{array}{l}\text { Junghuhnia nitida (Pers.) Ryvarden } \\
\text { KHL11903 }\end{array}$ & Sweden & EU118638 & EU118639 \\
$\begin{array}{l}\text { Luteoporia albomarginata F. Wu, Jia J. } \\
\begin{array}{l}\text { Chen \& S.H. He (Type) } \\
\text { Dai 15229 }\end{array}\end{array}$ & China & NR154126 & NG060338 \\
\hline
\end{tabular}

L. albomarginata

Mycoacia fuscoatra (Fr.) Donk

M. fuscoatra

M. nothofagi (G. Cunn.) Ryvarden

M. nothofagi

M. nothofagi

Mycoacia uda (Fr.) Donk

M. uda

Phlebia acanthocystis Gilb. \& Nakasone

P. acanthocystis

P. acerina Peck

P. acerina

P. aff argentina

P. ailaoshanensis C.L. Zhao

P. ailaoshanensis

P. albida Fr.

P. albida

P. albomellea (Bondartsev) Nakasone
Dai 15240

KHL13275

HHB-10782

BP:106925

KHL13750

AH31887

Kropp1

CBS 224.56

KUC20131001

FP150571

CLZhao 1582

CBS 125860

G6894

CLZhao 3882

GB 1833

CBS 214.67

FP-101843
CLZhao 3879
China

Estonia

USA

Hungary

France

Spain

USA

France

South

Korea

USA

China

Australia

French

Guiana

China

China

Spain

USA

USA
KU598874 KU598879

JN649352 JN649353

KP135365 KP135265

KX349908

GU480000 GU480001

GQ259416

KY948764

MH857593 MH869142

KJ668484 KJ668337

KY948767 KY948844

MH114855 -

MH863815 MH875278

MN994783 -

MH784918 MH784928

MH784919 MH784929

KY948748 KY948889

MH858951 MH870641

AY219369 


\begin{tabular}{|c|c|c|c|c|}
\hline \multirow[t]{2}{*}{ Species } & \multirow[t]{2}{*}{ Voucher/Locality } & \multirow[t]{2}{*}{ Locality } & \multicolumn{2}{|c|}{ GenBank Access Number } \\
\hline & & & ITS & LSU \\
\hline P. albomellea & no voucher & USA & L43378 & - \\
\hline P. aurea (Fr.) Nakasone & FCUG2767 & Turkey & HQ153409 & - \\
\hline P. aurea & $\begin{array}{l}\text { CFMR:DLL2011- } \\
100\end{array}$ & USA & KJ140614 & - \\
\hline P. brevispora Nakasone & BAFC-633 & Argentina & HM208154 & JX863667 \\
\hline P. brevispora & FBCC1463 & $\begin{array}{l}\text { Finland } \\
(?)\end{array}$ & LN611135 & LN611136 \\
\hline P. centrifuga P. Karst. & HHB-9239 & USA & KP135380 & KP135262 \\
\hline P. centrifuga & CBS 125890 & Sweden & MH864088 & MH875547 \\
\hline P. cf. martiana & OMC1242 & USA & KY948765 & - \\
\hline $\begin{array}{l}\text { P. cf. subserialis (Bourdot \& Galzin) } \\
\text { Donk }\end{array}$ & HHB-8715 & USA & KY948770 & KY948846 \\
\hline P. cf. subserialis & MS42b & USA & KJ831936 & - \\
\hline P. coccineofulva & HHB-11466sp & USA & KY948766 & KY948851 \\
\hline P. floridensis Nakasone \& Burds. & HHB-7175 & USA & KP135384 & - \\
\hline P. floridensis & FP-102562 & USA & KP135386 & - \\
\hline P. leptospermi (G. Cunn.) Stalpers & CBS 126031 & $\begin{array}{l}\text { New } \\
\text { Zealand }\end{array}$ & MH863894 & MH875355 \\
\hline P. leptospermi & TTT1607 & $\begin{array}{l}\text { New } \\
\text { Zealand }\end{array}$ & HQ153413 & - \\
\hline P. lindtneri (Pilát) Parmasto & GB501 & Norway & KY948772 & KY948847 \\
\hline P. livida (Pers.) Bres. & MG103 & Finland & HQ153415 & - \\
\hline P. livida & FP135046 & USA & KY948758 & KY948850 \\
\hline $\begin{array}{l}\text { P. livida subsp. tuberculata Hallenb. \& } \\
\text { E. Larss. }\end{array}$ & FCUG2716 & Russia & HQ153417 & - \\
\hline P. livida subsp. tuberculate & TTT1418 & $\begin{array}{l}\text { New } \\
\text { Zealand }\end{array}$ & HQ153419 & - \\
\hline P. lividina Hjortstam & HHB-4160 & USA & KY948755 & KY948849 \\
\hline P. lividina & HHB-9721 & USA & KY948756 & - \\
\hline
\end{tabular}




\section{Species}

Voucher/Locality Locality

GenBank Access Number

ITS

LSU

P. ludoviciana (Burt) Nakasone \&

Burds.

P. ludoviciana

P. nantahaliensis Nakasone \& Burds.

P. nitidula (P. Karst.) Ryvarden

P. nitidula

P. ochraceofulva (Bourdot \& Galzin)

Donk

P. radiata Fr.

P. radiata

P. rufa (Pers.) M.P. Christ.

P. rufa

P. serialis (Fr.) Donk

P. setulosa (Berk. \& M.A. Curtis)

Nakasone

P. setulosa

P. subochracea (Alb. \& Schwein.) J.

Erikss. \& Ryvarden

P. subserialis (Bourdot \& Galzin) Donk

P. subserialis

P. subserialis

P. subserialis

P. subserialis

P. subserialis

P. subserialis

P. subserialis

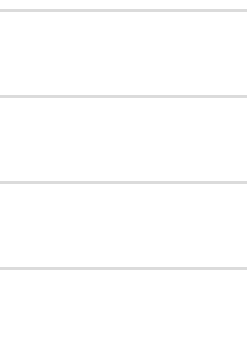

FD-427

G1085

HHB-2816

Nystroem

020830

T 407

FBCC295

Champ-81

AFTOL-ID 484

CFMR:5445

CBS 126034

FCUG2868

АH31879

HHB-6891

KGN $162-95$

CY097

UFMGCB 2216

UFMGCB 1883

KRT Iso 21

HHB-9768

РCT.28

HHB-5324
JSP 01-10
USA

French

Guiana

USA

Sweden

Sweden

France

USA

USA

New

Zealand

USA

Spain

USA

Sweden

Brazil

USA

Brazil

Brazil

USA

USA

Colombia

(?)

USA
Canada
KP135342 -

MF061328 -

KY948777 KY948852

EU118655

KY948747

LN611116

KX449485

AY854087 AF287885

KX065955 KX065989

MH863896 MH875357

HQ153429 -

GQ259417

KP135382 KP135267

EU118656 -

KR093857 -

HQ607954 -

HM997135 -

HQ377286 -

MN430941 -

KP135343 -

HQ248219

AB084620 


\begin{tabular}{|c|c|c|c|c|}
\hline \multirow[t]{2}{*}{ Species } & \multirow[t]{2}{*}{ Voucher/Locality } & \multirow[t]{2}{*}{ Locality } & \multicolumn{2}{|c|}{ GenBank Access Number } \\
\hline & & & ITS & LSU \\
\hline P. subserialis & CK463 & USA & MH474313 & MH483585 \\
\hline P. subserialis & CBS 211.54 & France & MH857296 & MH868828 \\
\hline P. subserialis & GB-240 & Sweden & AY219365 & - \\
\hline P. subserialis & V2EF16a & France & KT692553 & - \\
\hline P. subserialis & FBCC426 & Finland & LN611120 & - \\
\hline P. subserialis & 6829 (PUN) & India & KP715568 & - \\
\hline P. subserialis & PV352i & Ecuador & MH003356 & - \\
\hline P. subserialis & LSU0936 & USA & МT000447 & - \\
\hline P. subserialis & BRPCT8 & China & MT658054 & - \\
\hline P. subserialis & WZ-325 & China & MN856437 & - \\
\hline P. subserialis & WZ-245 & China & MN856367 & - \\
\hline P. subserialis & WZ-238 & China & MN856360 & - \\
\hline P. subserialis & WZ-90 & China & MN856249 & - \\
\hline P. subserialis & - & Portugal & FJ791134 & - \\
\hline $\begin{array}{l}\text { P. tremellosa (Schrad.) Nakasone \& } \\
\text { Burds. }\end{array}$ & KUC20121123 & $\begin{array}{l}\text { South } \\
\text { Korea }\end{array}$ & KJ668481 & KJ668334 \\
\hline P. tremellosa & CBS 217.56 & France & MH857589 & MH869138 \\
\hline $\begin{array}{l}\text { Phlebiporia bubalina Jia J. Chen, B.K. } \\
\text { Cui \& Y.C. Dai (Type) }\end{array}$ & Dai 13168 & China & KC782526 & KC782528 \\
\hline Phl. bubalina & Dai 15231 & China & KU598876 & KU598881 \\
\hline Sarcodontia crocea (Schwein.) Kotl. & BRNM:761841 & $\begin{array}{l}\text { Czech } \\
\text { Republic }\end{array}$ & KX831471 & KX831473 \\
\hline Sarcodontia crocea & BRNM:721609 & $\begin{array}{l}\text { Czech } \\
\text { Republic }\end{array}$ & KX831470 & KX831472 \\
\hline Scopuloides sp. & FP-150473 & USA & KP135355 & - \\
\hline $\begin{array}{l}\text { S. hydnoides (Cooke \& Massee) } \\
\text { Hjortstam \& Ryvarden }\end{array}$ & KHL11916 & Sweden & EU118665 & EU118665 \\
\hline S. hydnoides & FBCC423 & Finland & LN611119 & LN611119 \\
\hline S. rimosa (Cooke) Jülich & HHB-7042 & USA & KP135350 & KP135282 \\
\hline
\end{tabular}




\begin{tabular}{|lllll|}
\hline Species & Voucher/Locality & Locality & \multicolumn{2}{l|}{ GenBank Access Number } \\
\cline { 3 - 5 } & & & ITS & LSU \\
\hline S. rimosa & 11 G092 & $\begin{array}{c}\text { South } \\
\text { Korea }\end{array}$ & LC387824 & MK158344 \\
\hline S. rimosa & RLG-5104 & USA & KP135351 & KP135283 \\
\hline Uncultured fungus & CMH524 & USA & KF800613 & - \\
\hline
\end{tabular}

\section{Figures}



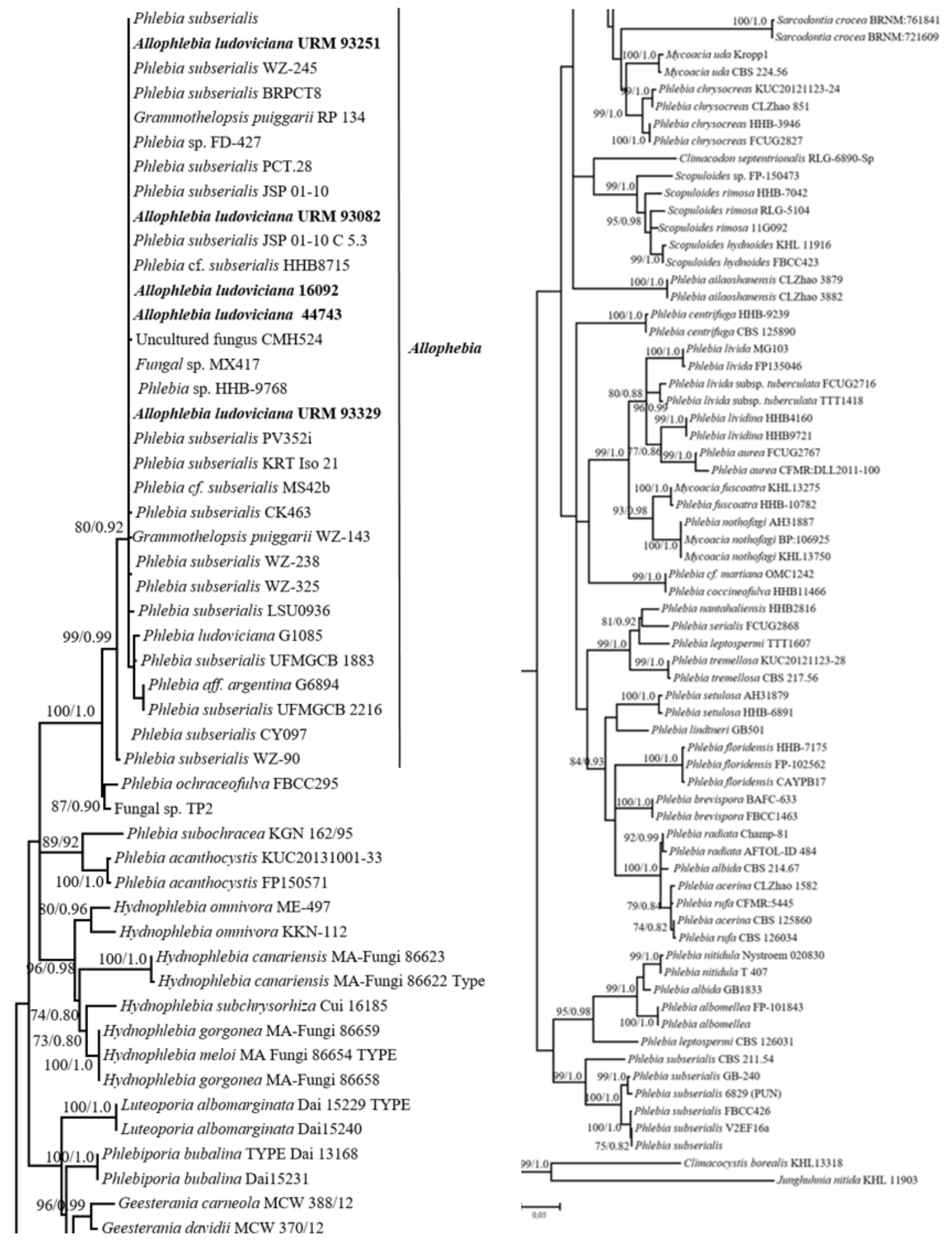

Figure 1

Phylogenetic reconstruction of sequences of Meruliaceae specimens inferred from a combined dataset of ITS and nLSU. Parsimony bootstrap generated by ML (higher than $60 \%$ ) and BA posterior probabilities (higher than 0.70) are showed along the branches, respectively. The sequences in bold were generated in this study 


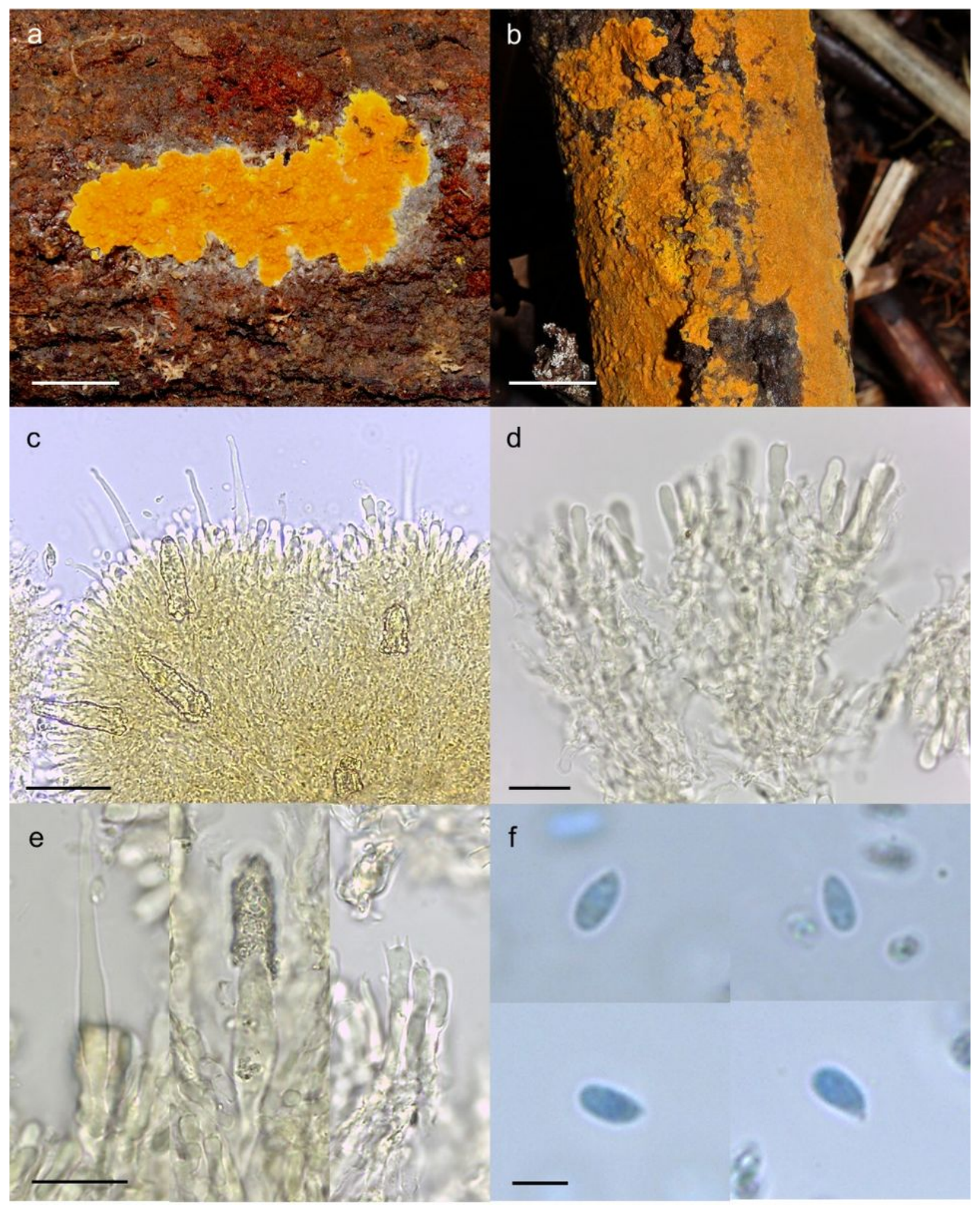

Figure 2

Allophlebia ludoviciana. a-b. Fresh specimens (a. URM 93249, b. URM 93251); c. Leptocystidia; d. Basidia; e. Metuloids; f. Basidiospores. Bars: a, b, $c=1 \mathrm{~cm} ; \mathrm{c}=50 \mu \mathrm{m} ; \mathrm{e}, \mathrm{f}=20 \mu \mathrm{m}$ 